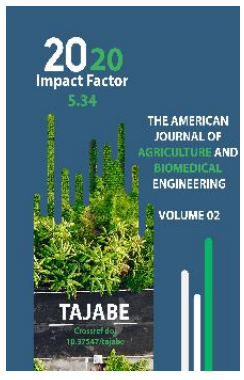

Copyright: Original content from this work may be used under the terms of the creative commons attributes 4.0 licence.

\section{Experimental Fight Against The Weeds In Winter Wheat Fields Maxier- Em.K And Effectiveness Of Herbicide}

Rakhmonova Madina Kimsanboevna

(Phd) Lecturers Of Andijan Institute Of Agriculture And Agrotechnology, Uzbekistan

Mirabdullaeva Nilufar

(Phd) Lecturers Of Andijan Institute Of Agriculture And Agrotechnology, Uzbekistan

Parpieva Makhmuda

(Phd) Lecturers Of Andijan Institute Of Agriculture And Agrotechnology, Uzbekistan

\title{
ABSTRACT
}

We have studied the biological efficiency of $8 \%$ conc. Emulsions Topic BG, and conc. emulsions Maxier in our experiment (standard).

And the results showed that in the use of quantitative doses of $0.4 \mathrm{I} /$ ha of $8 \%$ conc. emulsion Topik BG effectiveness was $82.7 \%$ of another drug- and conc. Maxier's emulsion in the amount of 0.9-1.0 I/ ha, $83.2-86.2 \%$ compared to control variants.

\section{KEYWORDS}

winter wheat, weeds, herbicide, experience, preparation, conc. emulsion Maxiera

\section{INTRODUCTION}

It is known that grain growing as one of the main branches of agriculture is developing in our country. And one of the resource-efficient agrotechnologies in achieving high and highquality grain crops is weed control.

We know that the weeds get worsen the quality of crops grown in grain fields and promote the spread of pests and diseases, as in most cases weeds are a source of intermediate infection, leading to a $30-35 \%$ reduction in yield with serious damage to plant growth and development.

In addition, they negatively can affect the growth and development of the plant, as well as the loss of product quality and yield during the harvest period. In this regard, weed treatment with chemical herbicides, cleaning 
of seed materials, pest and disease control are required.

Weeds such as Raygras (Lolium perenne), Echinochloa crus-galli, Foxtail (Alopecurus geniculatus), Wild oats (Avena fatua), which are now widely used in grain fields, increase the productivity of agricultural crops and crop yields. in decline, is a major factor that negatively affects the deterioration of product quality. Weeds are also spreading from year to year, causing serious damage to crop yields, leading to a $10 \%$ decline in cereals, $13.4 \%$ in legumes, $7.5 \%$ in cotton, $6 \%$ in potatoes and $10.8 \%$ in vegetable crops.

Having it in mind, the effective use of chemicals, especially herbicides, is important in the control of weeds, along with the timely and quality implementation of mechanical, agrotechnical, biological and other measures. Currently, the State Commission for Chemicals and Plant Protection of the Republic of Uzbekistan (State Chemical Commission) in the control of weeds in the harvest of winter wheat approved chemical and biological means of protection against plant pests, diseases and weeds in agriculture of the Republic of Uzbekistan. and herbicides, which are included in the list of plant growth regulators, are widely used to achieve effective and high yields.

Taking into account the above, in the field of the Central Experimental Farm of the Research Institute of Cereals and Legumes, a new chemical Maxiyer-em.k against weeds of winter wheat variety Uzbekistan-25. We conducted drug field experiments on April 10, 2019. In the experimental weed treatment was carried out at an air temperature of 18-20 oC, relative humidity of $50 \%$.

The experiments were performed on the following system.

1. Control (unprocessed)

2. Topic BG, $8 \%$ em.k -0.4 l/ ha (standard)

3. Maxier- em.k- 0.9 l/ha ..

4. Maxi-em.k-1.0l/ha

We have carried our experiments out in 4 variants and 3 repetitions on the basis of guidelines "Testing of insecticides, acaricides, biologically active substances and fungicides" developed by the Chemical Commission (2004). And we conducted it on the field planted with Uzbekistan-25 varieties of winter soft wheat. The types and names of weeds found in the experimental field were taken into account according to the experimental options. See the table below. 
TABLE 1

\begin{tabular}{|c|c|c|c|}
\hline № & A type of cereal weed & $\begin{array}{c}\text { Date of } \\
\text { processing }\end{array}$ & $\begin{array}{c}\text { Average } \\
\text { number of } \\
\text { weeds per } 1 \\
\text { sq.m. }\end{array}$ \\
\hline 1. & Raygras pastbishchnyy (Lolium perenne) & \multirow{4}{*}{$\begin{array}{c}\text { April 10, } \\
2019\end{array}$} & 7 \\
\hline 2. & Kurmak (Echinochloa crus-galli) & & 9 \\
\hline 3. & Tulki dum (Alopecurus geniculatus) & & 8 \\
\hline 4. & Wild oats (Avena fatua) & & 7 \\
\hline
\end{tabular}

We have carried out our experiments in every 15 days to determine, monitor and record the biological effectiveness of the drugs on the options. Before conducting field experiments with the chemical Maxier-em.k in the experiment, weeds per $1 \mathrm{~m} 2$ of land were treated according to the options before processing in the harvesting phase of winter wheat. In the control variant of the experiment, the average was 8.5 , Topic BG, $8 \%$ em.k, $0.4 \mathrm{l} /$ ha (standard), in the experimental variant, 7.2 , in the experimental variant, $0.9 \mathrm{l} /$ ha, in the experimental variant, the average 8 , 5, Maxier-em.k-1.0 I/ ha in the experimental variant, an average of 6.5 weeds were found. 45 days after treatment, the number of weeds per $1 \mathrm{~m} 2$ averaged 10.2 in the control variant, Topic BG, 8\% em.k $0.4 \mathrm{l} /$ ha (standard) in the experimental variant 0.8, Maxier-em.k-o , An average of 0.82 aliens in the experimental variant of $9 \mathrm{I} / \mathrm{ha}$, and an average of 0.45 aliens in the experimental variant of Maxierem.k Maxier-em.k 1.0 I/ ha.

When we analyzed the results which we have obtained, the average biological efficacy was determined every 45 days after administration of the drug, with Topic BG, $8 \%$ em.k $0.4 \mathrm{I} /$ ha (standard) in the experimental variant $82.7 \%$, Maxier-em.k Maxier-em.k. Biological efficiency was $83.2 \%$ in the experimental variant of $0.9 \mathrm{l} /$ ha, $86.2 \%$ in the experimental variant of Maxier-em.k 1.0 I/ ha. 
The American Journal of Agriculture and Boimedical Engineering (ISSN - 2689-1018)

Published: November 30, 2020 | Pages: 69-73

See the data, presented in Table 2 below

Table 2

Biological efficacy of Maxier-em.k against weeds (in \%)

\begin{tabular}{|c|c|c|c|c|c|c|c|c|c|c|c|c|}
\hline \multirow[b]{2}{*}{ № } & \multirow[b]{2}{*}{$\begin{array}{l}\text { The name of } \\
\text { the weed }\end{array}$} & \multicolumn{4}{|c|}{$\begin{array}{c}\text { Number of weeds per } 1 \mathrm{~m} 2 \text { before } \\
\text { processing }\end{array}$} & \multicolumn{4}{|c|}{$\begin{array}{c}\text { Number of weeds per } 1 \mathrm{~m} 245 \text { days } \\
\text { after treatment }\end{array}$} & \multicolumn{3}{|c|}{ Biological efficiency\% } \\
\hline & & 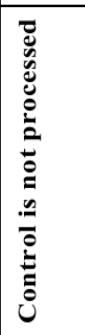 & 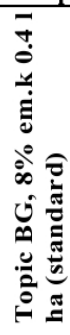 & 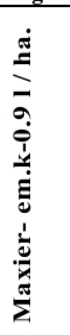 & 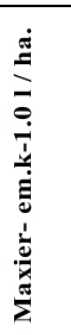 & 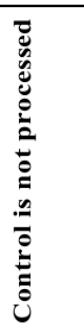 & 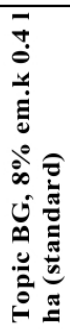 & 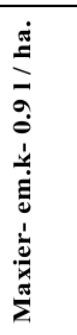 & 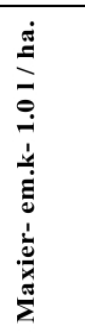 & 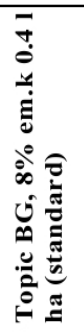 & 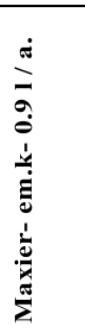 & 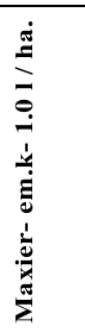 \\
\hline 1 & \begin{tabular}{|l|} 
Raygras \\
(Lolium \\
perenne)
\end{tabular} & 8 & 7 & 8 & 6 & 9 & 0,7 & 0,7 & 0,3 & 90 & 91,2 & 95,0 \\
\hline 2 & 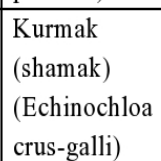 & 10 & 9 & 9 & 8 & 14 & 1 & 1,0 & 0,7 & 88,8 & 88,8 & 91,2 \\
\hline 3 & \begin{tabular}{|l|} 
Tulki dum \\
(Alopecurus \\
geniculatus)
\end{tabular} & 9 & 7 & 9 & 6 & 10 & 0,7 & 0,7 & 0,2 & 90 & 92,2 & 96,6 \\
\hline 4 & $\begin{array}{l}\text { Wild oats } \\
\text { (Avena } \\
\text { fatua) }\end{array}$ & 7 & 6 & 8 & 6 & 8 & 0,7 & 0,9 & 0,6 & 90 & 88,7 & 90,0 \\
\hline 5 & Average & 8,5 & 7,2 & 8,5 & 6,5 & 10,2 & 3,1 & 3,3 & 1,8 & 82,7 & 83,2 & 86,2 \\
\hline
\end{tabular}

\section{CONCLUSION}

In conclusion we can say that the results of the table above shows that Topic BG against cereal weeds, $8 \%$ em.k herbicide at $0.4 \mathrm{I} / \mathrm{ha}$. when used in moderation and its efficiency was found to be $82.7 \%$. Our experiments have shown that when applied at a dose of 0.9-1.0 I / ha Maxier-em.k gives a high efficiency of 83.2-86.2\% against cereal weeds.

\section{REFERENCES}

1. Pulatov O., Arslonov M., etc. "Weeds and their control” Andijan 2013.

2. Rizaev.Sh., Muminov K. Uzbek Agricultural Journal "Weed Kushandasi" 2015 № 8 issue 31 page
3. Dospexov B.A. "Methods of field experiment" Moscow 1985, pp. 12-30

4. Khojaev Sh.T., Kholmurodov E.A. "Fundamentals of entomology, crop protection and agrotoxicology" Tashkent, 2008, pp. 30-80.

5. Sulaymonov, B. A., Isashova, U. A., Rakhmanova, M. K., Parpiyeva, M. Q., \& Rasulov, U. S. (2019). Systematic analysis of the dominant types of entomophages in fruit orchards. Indonesian Journal of Innovation Studies, 8.

6. Anorbayev, A. R., Isashova, U. A., Rakhmonova, M. K., \& Jumayeva, A. N. (2019). Development and Harm of Liriomyza Sativa Blanchard leaf--mining Flies. Indonesian Journal of Innovation Studies, 
The American Journal of Agriculture and Boimedical Engineering (ISSN - 2689-1018)

Published: November 30, 2020 | Pages: 69-73

Doi: https://doi.org/10.37547/tajabe/Volume02Issue11-13

2020:5.34

OCLC - 1121105746

7. Yusupovich, K. S. (2020). The Emergence Of Religious Views Is Exemplified By The Southern Regions. The American Journal of Social Science and Education Innovations, 2(10), 143-145. 